\title{
Sustainability reporting and impression management: A case study in the oil and gas industry
}

\author{
Maria-Silvia Săndulescu ${ }^{1, a}$
}

${ }^{\mathrm{a}}$ The Bucharest University of Economic Studies, Romania

„...one is dealing not only with figures and statements but also with life and death" (Matilal \& Höpfl, 2009: 953)

\begin{abstract}
Research Question: How are corporate narratives used to build and restore corporate legitimacy?

Motivation: Under certain circumstances, managers may be motivated to control stakeholders' perception regarding organizational performance. As such, this study makes use of sustainability disclosures that were issued both prior and after a major incident in order to analyse the use of corporate narratives.
\end{abstract}

Idea: The paper relies on the case of KazMunayGas International, with a view of analysing the evolution of the messages used in framing occupational safety issues.

Data: The sustainability reports and corporate press releases issued by KMGI for the period 2015 and 2016 were explored.

Tools: A manual content analysis was performed in order to evaluate the use of evaluations, repetitions and performance comparisons.

Findings: A trend towards the use of positive evaluations of organizational performance was observed. Following the negative event, the use of several impression management strategies was documented. This reflected a general tendency to defend corporate legitimacy by favourably shaping the corporate image associated with occupational safety.

Contribution: The paper aims to complement previous research on social and environmental disclosures that analysed the biased use of tone and graph distortions. In addition, the paper

${ }^{1}$ Corresponding author: Department of Accounting and Auditing, The Bucharest University of Economic Studies, Piața Romană no. 6-8, sector 1, București, Romania. Tel: +4021 319 19 00; email address: maria.sandulescu@cig.ase.ro 
contributes to a literature that focused mainly on environmental disclosures by drawing on a case study that reveals occupational safety issues.

Keywords: impression management, non-financial performance, legitimacy, corporate narratives

JEL Codes: M14, M42, M54

\section{Introduction}

This study's focus is on the way language is used in corporate narratives. The paper relies on the case of KazMunayGas International (hereafter, KMGI), a group which operates in the oil and gas industry. In 2016, the group raised the public' awareness following a blast that caused the death of two employees. Following the criminal prosecution, two subsidiaries of KMGI were put on trial for failure to take the legal occupational health and safety measures, bodily harm by negligence, manslaughter and accidental pollution (Mediafax, 2016). In this view, it becomes relevant to analyze the manner in which corporate disclosures were used to build and restore corporate legitimacy concerning occupational safety.

The core assumption of impression management is that under certain circumstances, managers may be motivated to control stakeholders' perception regarding organizational performance (Merkl-Davies et al., 2011). While previous researchers focused mainly on the use of impression management strategies in relation with the corporate financial performance (Schrand \& Walther, 2000; Clatworthy \& Jones, 2003; Short \& Palmer, 2003; García Osma \& Guillamón-Saorín, 2011; GuillamónSaorín \& Martínez-López, 2013), this study makes use of sustainability disclosures in order to assess the framing of occupational health and safety performance.

Sustainability disclosures provide additional information which may be used by the stakeholders in their decision making process. In other words, these corporate narratives provide context to the financial statements. In this view, "where society is not satisfied that the organization is operating in an acceptable, or legitimate, manner, [it] will effectively revoke the organization's 'contract' to continue its operations" (Deegan, 2002: 293) which may in turn negatively influence the future financial performance of the companies. As such, numerous studies have attempted to explain the use of impression management tactics in social and environmental disclosures through a legitimacy theory lens. The existing literature leads us to assume that when organizations face certain threats to their social and environmental legitimacy, corporate narratives can be used as persuasive devices. In this view, impression management strategies are used in order to frame a more favourable image that may influence stakeholders' perceptions regarding organizational 
behaviour (Deegan, 2002; Patten, 2002; Cho \& Patten, 2007; Cho, 2009; Cho et al., 2012b).

As per the aim of this study, the sustainability reports and corporate press releases issued by KMGI for the period 2015 and 2016 were explored. The paper evaluates the use of the following impression management strategies: evaluation, repetition as well as the biased use of performance comparisons. The results highlighted a trend towards the use of positive evaluations of organizational performance. In addition, after the incident a change in the use of narratives was documented. This entailed the use of several impression management strategies in order to defend the legitimacy and to favourably shape the corporate image associated with occupational safety (Cho, 2009; Beelitz \& Merkl-Davies; 2012).

The paper aims to complement previous research on social and environmental disclosures that analysed the biased use of tone (Cho et al., 2010) and graph distortions (Cho et al., 2012a, 2012b). In addition, the paper contributes to a literature that focused mainly on environmental disclosures (Cho \& Patten, 2007; Cho et al., 2010) by drawing on a case study that reveals occupational safety issues.

The remainder of this paper is segmented as follows. A review of the literature is presented in section 2 . The research background and methodology are described in section 3 and section 4 respectively. The results are presented and discussed in section 5. The paper concludes with a discussion of the contributions and potential implications.

\section{Literature review}

\subsection{Legitimacy theory}

Over the past two decades, the volume of organizational communications on social and environmental issues has increased (Albu et al., 2013; Mäkelä \& Laine, 2011). These disclosures play an important role in the analysis of sustainable practices carried out by companies (Moneva et al., 2006). There are various means of communicating information such as annual reports, press releases, sustainability reports, or the website (Mahadeo et al., 2011). As these disclosures are mainly voluntary in nature, The Global Reporting Initiative issued sustainability reporting standards that aimed to help the companies to better understand and communicate their impact on society (Dando \& Swift, 2003).

However, the transparency of these forms of communication has become a controversial topic among researchers (Mahadeo et al., 2011; Boiral, 2013). The existing literature leads us to assume that organizational communications on social and environmental issues serve the private interests of managers and organizations of which they are part (Adams, 2004; Cho, 2009; Laine, 2009; Tregidga \& Milne, 
2006; Mäkelä \& Laine, 2011; Cho et al., 2010; Boiral, 2013; Gray, 2006). By highlighting the positive performance, it is possible to hide the negative one and the lack of a sustainable behaviour (Boiral, 2013; Moneva et al., 2006).

The most widely used theory to explain organizational communications on social and environmental issues is legitimacy theory (Campbell et al., 2003). According to this theory legitimacy is

„....a condition or status which exists when an entity's value system is congruent with the value system of the larger social system of which the entity is a part. When a disparity, actual or potential, exists between the two value systems, there is a threat to the entity's legitimacy" (Lindblom, 1994: 2, in Gray et al., 1995)

In other words, legitimacy is a resource that can be used to achieve organizational goals (Ashforth \& Gibbs, 1990, in Suchman, 1995; Dowling \& Pfeffer, 1975, in Suchman, 1995). Moreover, this theory suggests the existence of a social contract between companies and society (Deegan et al., 2002). Failure to comply with this social contract may threaten companies' ability to continue their business (Deegan et al., 2002; O'Donovan, 2002). In this view, companies are motivated to use certain communication strategies to illustrate that they meet the norms and expectations of the society in which they operate (Adams, 2004; Cho, 2009; Deegan, 2002; O'Donovan, 2002; Deegan et al., 2002; Patten, 2002; Cho \& Patten 2007; Boiral, 2013; Cho, Freedman \& Patten 2012a; Hooghiemstra, 2000; Tilling \& Tilt, 2010). The chosen strategies depend on the managers' ability to evaluate the requirements of the social contract, as well as on the way in which the company is perceived in society (Deegan et al., 2002). The requirements of the social contract are dynamic in nature as the society's expectations may change in time (Deegan et al., 2002). However, a negative event may represent a threat to corporate legitimacy. As such, managers have to identify those relevant stakeholders that have the capacity to grant or revoke the legitimacy of the company (Neu et al., 1998, in O'Donovan, 2002).

According to Lindblom (1994, in Gray et al., 1995) one strategy to defend legitimacy relates to informing relevant stakeholders about changes in corporate' activity, following poor performance. Another strategy aims to change the perception of stakeholders without changing organizational behaviour. The company can use this technique when its image is misrepresented in the stakeholder's perception. The third strategy entails the manipulation of public opinion by presenting events or information that have the role of switching the attention away from negative events. Finally, the company can adopt the strategy of changing the stakeholders' expectations related to the responsibilities that the company should fulfil.

Consequently, organizational legitimacy is granted and revoked by the society (O’Donovan, 2002). According to Suchman (1995), companies cannot meet the 
expectations of all stakeholders and also cannot fully violate the values of the society in which they operate. However, corporate reporting plays an important role in shaping the company's legitimacy (Suchman, 1995).

It is necessary to distinguish between legitimacy (status) and legitimation (process) (Gray et al., 1995). The information provided by a company that fulfils its obligations regarding social and environmental responsibility, is a proof of legitimacy (Gray et al., 1995; Hughes, Anderson \& Golden, 2001). However, when a company violates these obligations and disseminates information about positive aspects, the corporate narratives reflect a form of legitimization (Gray et al., 1995; Hughes et al., 2001). As such, a threat to their social and environmental legitimacy may trigger the use of impression management strategies in order to frame a favourable image of the company's social and environmental performance (Cho et al., 2012b).

Existing studies have focused on events that may lead to non-compliance with social norms and values. In particular, these studies focused on events such as restructuring and reorganization (Arndt \& Bigelow 2000), privatizations (Craig \& Amernic, 2004; Craig \& Amernic, 2006; Craig \& Amernic, 2008), disasters that affected the environment (Hooghiemstra, 2000; Cho, 2009; Beelitz \& Merkl-Davies, 2012) as well as corporate scandals (Breton \& Côté 2006; Lightstone \& Driscoll, 2008). Thus, the literature has shown that in controversial times, narration is used as a means of persuasion in order to restore legitimacy. Moreover, existing studies suggest that although companies adopt the GRI methodology in preparing sustainability reports, they still do not have a responsible behaviour (Moneva et al., 2006). Therefore, the international GRI reporting framework is used as a new means of legitimizing organizational behaviour (Moneva et al., 2006).

In this view, Cho et al., (2010) empirically analysed the biased use of language and verbal tone as a tool for managing stakeholder's perception. The authors provide evidence that worse environmental performers have a tendency to obfuscate their poor results. The biased use of graphs in corporate sustainability reports was also assessed. Particularly, Cho et al. (2012a; 2012b) analysed the differences in presentation of favourable and unfavourable items and the use of distorted graphs. The authors suggest that information "appears to be manipulated by the firms to enhance a positive image and to obfuscate negative trends". In addition, Cho et al. (2012b) claim that sustainability reports themselves are an impression management strategy developed in order to legitimize the activities carried out by companies.

\subsection{Impression management strategies}

The existing literature identifies three ways in which information can be emphasised in corporate narratives. One of these entails the use of evaluative statements. 
According to Fairclough (2003), evaluative statements are statements by which a particular object, place, person, situation, or action is evaluated as desirable or undesirable, positive or negative. This can be done by using adjectives, adverbs, nouns or verbs (eg I love this book / the book is fantastic / the book is well written). Merkl-Davies and Koller (2012) suggest that evaluation can "be used strategically to guide audiences' interpretations of organizational activities and outcomes" (Merkl-Davies \& Koller, 2012: 189). The authors analysed the letter to shareholders published by the British company Meggitt PLC in 2002. Using the concept defined by Fairclough (2003), Merkl-Davies and Koller analysed evaluation in the use of adjectives, adverbs and nouns.

Another impression management strategy is repetition. This strategy is a mechanism of rhetoric that provides both emphasis (Davison, 2008; Merkl-Davies \& Brennan, 2007) and memorability because certain keywords are repeated in the text (Davison, 2008). Moreover, existing studies have illustrated that the reader may come to regard the repeated information as true as the level of acceptance of the ideas increases (Hawkins \& Hoch, 1992, in Pollock \& Rindova, 2003).

The biased use of performance comparisons is another impression management strategy (Merkl-Davies \& Brennan, 2007). This strategy requires the selection of benchmarks that can highlight the favourable evolution of results (Schrand \& Walther, 2000; Short \& Palmer, 2003). In this view, managers can choose as a benchmark the results recorded in previous years, an industry average, the results recorded by the main competitors, etc. According to Brennan et al. (2009), performance comparison is a way of reinforcing quantitative information. The authors suggested that this strategy is influenced by the evolution of results, assuming a general tendency to use performance comparisons in the context of positive results. The same tendency was also documented by Guillamón-Saorín și Martínez-López (2013). In contrast, García Osma and Guillamón-Saorín (2011) suggested that effective corporate governance mechanisms play an important role in limiting the use of impression management.

Prior research has mainly analysed impression management in the context of annual reports (Clatworthy \& Jones, 2003; Clatworthy \& Jones, 2006), press releases (García Osma \& Guillamón-Saorín, 2011; Guillamón-Saorín \& Martínez-López, 2013) and earnings conference calls (Price et al., 2012). This paper seeks to complement the body of work on impression management that studied social and environmental disclosures (Hughes et al., 2001; Patten, 2002; Adams, 2004; Cho \& Patten, 2007; Cho et al., 2012a; Boiral, 2013; Rodrigue, 2014; Rodrigue et al., 2015) by evaluating the use of evaluation, repetition and the biased use of performance comparisons. These strategies were considered in order to extend the existing studies that analysed the biased use of tone and graphs (Cho et al., 2012b; Cho et al., 2010). 
Consequently, this paper aims to answer the following research question: RQ - How are corporate narratives used to build and restore organizational legitimacy?

\section{Research background}

A member of the European Union since January 2007, Romania has transposed the provisions of European Directive 2014/95/EU as regards disclosure of non-financial and diversity information by certain large undertakings and groups through the Order of the Ministry of Public Finance no. 1938/2016. The order is addressed to public interest entities that have more than 500 employees, at the balance sheet date. These entities are required to include as of January 1, 2017 in the directors' report or in a separate one:

"a non-financial statement that contains, to the extent necessary to the understanding of the entity's development, performance and position and the impact of its business, information relating to at least environmental matters, social and employee-related matters, respect for human rights, anti-corruption and bribery matters" (OMFP 1938/2016).

In this view, companies can use both national, European Union or international frameworks. Subsidiaries are exempted from fulfilling this obligation if this information is included in the consolidated report of the parent company.

Previous research that focused on the Romanian context (Băleanu et al. 2011, Zaharia \& Grundey, 2011; Obrad et al. 2011; Gușe et al. 2016; Dumitru et al. 2017) concluded that CSR reporting is the outcome of a mandatory requirement than of a real involvement in sustainability practices. Moreover the researchers highlight that this topic is mainly used by the companies in order to favourably portray corporate image. As such, Gușe et al. 2016 point out to the fact that

„In Romania there are two different types of companies in terms of CSR. On the one hand, companies who are required by legislation to make CSR-related disclosures do not display significant interest in developing their reporting practices outside the legislative requirements. Moreover, their reporting practices are oriented toward complying with legislation and the disclosures explicitly refer to this aspect. Meanwhile, the companies which engage in CSR initiatives are not targeted by legislation, their efforts being driven by legitimacy claims." (Gușe et al., 2016: 333) 
In addition Dumitru et al. (2017) suggest that the quality of the information disseminated by the companies is low and limited. However, the authors document that companies operating in industries that are prone to environmental pollution and those in which the state is a shareholder tend to disclose non-financial information of a higher quality. Moreover, the article emphasizes both the influence of trade unions and the lack of pressure from the society in which companies operate.

KMGI Group (formerly named The Rompetrol Group) is a major player in the Romanian oil and gas industry. The group is owned by Kazakhstan's national oil and gas operator, KazMunayGas JSC. KMGI carries out operations in 16 countries throughout Europe, Central Asia and North Africa, Romania being its base of operations. Refining and petrochemicals represent one of the main business units of the group (KMGI, 2017). Its subsidiary, Rompetrol Rafinare S.A., owns one of the most modern refineries in South-Eastern Europe, Petromidia. The refinery has a processing capacity of over 5 million tons per year. Its strategic position, on the Black Sea shore, facilitates the import and export of crude oil and refined products.

On August 22, 2016 an explosion occurred at Petromidia refinery. Two employees of KMGI' subsidiary, Rominserv SRL, suffered burns while two others lost their lives. The employees were working to repair a pipeline that carried heated crude vacuum distillate at temperatures between 360 and $380^{\circ} \mathrm{C}$. Following the criminal prosecution, Rompetrol Rafinare S.A., Rominserv SRL and employees of the two companies were put on trial for failure to take the legal occupational health and safety measures, bodily harm by negligence, manslaughter and accidental pollution (Mediafax, 2016). Although KMGI emphasized that the "company complies with safety legislation and work protection, as well as the environmental regulations", the prosecutors claimed that:

From Friday 19 to Monday 22, when the explosion took place, a number of 1.600 .000 gas emission alarms were recorded in the control room, all ignored. 30 minutes before, there were over 300 alarms, ignored as well. (Niță, in Litoral TV, 2016)

In spite of the fact that the hole in the pipeline was noticed by the employees, the production process was not stopped. In a press conference, the prosecutors also highlighted that:

During the explosion, the blow threw a 200 litre extinguisher tube, somewhere over a mass of $300 \mathrm{~kg}$, in a tank containing hydrogen sulphide and several tons of gasoline. Luck has caused the tank to deteriorate severely but not crack. I am thinking of the horror that would have happened if the hydrogen sulphide and the explosive gasoline provoked a chain reaction. For your knowledge, if you breathe hydrogen sulphide once, you have no time for a second breath. (Niţă, in Litoral TV, 2016) 
As both subsidiaries were accused for negligence and failure to take the legal occupational health and safety measures, this case represents a fruitful background for the analysis of sustainability disclosures disseminated by the group, both prior and following the event.

\section{Research methodology}

For the purpose of this study, KMGI' sustainability reports and corporate press releases for the period 2015-2016 were considered (2 sustainability reports and 1 press release). The period was chosen in order to put the 2016 accident into a broader context. As a result, the analysis focuses on the manner in which the company attempted to "build" and further "renovate" the image associated with the concept of occupational safety. In order to get a more comprehensive understanding of the context, data from various media outlets was used. This material served only as supplementary information as the study adopts a preparer perspective on impression management (Merkl-Davies \& Brennan, 2007).

The English version of the sustainability reports and press releases published by KMGI was obtained from the group's website (https://kmginternational.com/). The use of this version facilitates both reproducibility (Krippendorff, 2004) and comparison with prior results documented in the literature.

Sustainability reports published by KMGI are prepared according to GRI reporting standards. These reports follow a standard structure that includes six sections. The first section includes details on the report, the CEO's message as well as interviews with company representatives, corporate governance issues, details on stakeholders as well as materiality issues. The second section provides a description of the group which includes, inter alia, the code of ethics and conduct while the other sections deal with environmental issues, the company's impact on the community and the business environment. The analysis of the sustainability reports mainly focused on the section entitled "Our people" which includes details on workplace safety management, but details on this topic included among the other sections of the report were also considered.

The study concentrates on "what is and what is not said, rather than how much is said" (Tregidga \& Milne, 2006: 224). In this view, the analysis entailed a careful reading of all the texts followed by subsequent re-readings and interpretations of selected extracts. This facilitated a full understanding of the meaning of text. The use of the following impression management strategies was assessed:

1. Evaluation - the use of adjectives and adverbs in describing the performance of the company related to occupational safety. According to Fairclough, (2003) evaluations are used in order to describe a particular object, place, 
person, situation or action as desirable or undesirable, positive or negative. The following is an illustrative example of a statement which includes positive evaluations:

„This aim is met through a constant risk evaluation and the implementation of strict safety measures, which are diligently applied throughout our entire value chain, to our employees, suppliers, contractors and subcontractors."

Merkl-Davies and Koller (2012) suggest that evaluations can be used strategically to guide audiences' interpretations of organizational activities and outcomes.

2. Repetition - a word is repeated when it is mentioned more than once in the text (Brennan et al., 2009). Drawing from the methodology used by Davison (2008), enumerations were also considered. Enumerations entail the use of a list of three or more words, separated by a comma, that reflect the same idea. According to the author, the use of lists is a rhetorical means by which the repetition and hence the emphasis of an information can be achieved.

3. The biased use of performance comparisons: this strategy involves the use of a benchmark in order to favourably portray performance evolution (Brennan et al., 2009; García Osma \& Guillamón-Saorín, 2011; GuillamónSaorín \& Martínez-López, 2013; Schrand \& Walther, 2000; Short \& Palmer, 2003). The extent to which the company presents performance indicators for the current period by referring to the results of previous years was analysed, in order to reflect a positive image or to hide negative results. The biased use of performance comparisons was considered not only in text (Schrand \& Walther, 2000; Short \& Palmer, 2003; Brennan et al., 2009; García Osma \& Guillamón-Saorín, 2011; Guillamón-Saorín \& Martínez-López, 2013) but also in the use of tables. Particularly, the study analysed whether the company presents the current year performance indicators by reference to the results from previous years in order to reflect a positive image or to conceal negative results.

\section{Results and discussions}

In the sustainability report published by KMGI in 2015, the CEO describes the company's employees as "our most important asset". This description is repeated in all the reports published by the company and it emphasises the increased importance ascribed to the employees: 
„And because employees are our most important asset, we developed a management system specially dedicated to our staff that supports the human capital development, by assuring the necessary training to provide skills and business competences in order to achieve the high standards assumed and the safety of our staff." (KMGI, 2015)

However, a similar wording was used in the description of one of the group's refineries:

„the bond with the natural environment around our most prized asset: Petromidia refinery." (KMGI, 2015)

Given the degree of similarity of the two forms of positive evaluation, the credibility of these statements may be questioned. In this view, Goffman (1956) provides a suggestive example that illustrates the previous observation:

„If you have paid a compliment to one man, or have used toward him any expression of particular civility, you should not show the same conduct to any other person in his presence. For example, if a gentleman comes to your house and you tell him with warmth and interest that you 'are glad to see him', he will be pleased with the attention, and will probably thank you; but if he hears you say the same thing to twenty other people, he will not only perceive that your courtesy was worth nothing, but he will feel some resentment at having been imposed on." (Goffman, 1956: 32)

The concept of occupational safety is described in the section of the report titled „Our People” as "a crucial part of our strategy":

„The safety of our employees and contractors is a matter of the highest interest and commitment for our company, being a crucial part of our strategy and of the way we do business." (KMGI, 2015)

Moreover, the concept is extended so that it includes both that of employees and the safety of the community in which the group operates. Davison (2008) mentions that the use of lists as a rhetorical device emphasises the message that the sender intends to convey. In other words, the concept of safety is highlighted:

„We take good care of the health, safety and security of our employees, suppliers and communities where we undertake our activities." (KMGI, 2015) 
„This is done by establishing, implementing and maintaining a comprehensive QHSE Management system and by accepting the moral responsibilities of promoting and protecting the Health, Safety and Well Being of everyone involved in our activities, the employees of our company and our partners, their families, our clients and suppliers, the communities located near our work places and the public influenced by our work environment." (KMGI, 2015)

In the excerpt above, the use of the adjective "comprehensive" illustrates a positive evaluation of the management system that deals with occupational health and safety issues. Moreover, the use of the list of verbs (i.e. establishing, implementing and maintaining) reflects the fact that this system is a functional one and further emphasises its importance within the company. The following quotes support this positive assessment as the group claims the use of "the highest standards" in this field and the compliance with legal requirements:

„the success and strength of our business lies first and foremost with our staff and in order to keep it that way will promote the highest standards in Quality, Health, Safety and Environment." (KMGI, 2015)

„Therefore, we operate in full compliance with national and international legislation to ensure a safe working place" (KMGI, 2015)

„Moreover, KMG International continually evaluates its health and safety principles and procedures throughout its operations to ensure that they are up to standards." (KMGI, 2015)

„we have provided additional safety in the context of difficult market conditions." (KMGI, 2015)

It can be noticed that the last quote states that the company ensured superior safety conditions "in the context of difficult market conditions". The legitimacy of this statement may be questioned as the safety of people should not be influenced by market conditions.

The performance indicators related to occupational safety issues are presented in the sustainability report in a table. Figure 1 is an illustration of this table. The table is further interpreted and even extended in the text, as the results are compared to the ones from 2010: 
„No events resulting in loss of human lives were recorded at KMG International since 2010 and all the occupational health and safety activity performance indicators registered at Group level showed positive evolution." (KMGI, 2015)

Figure 1. Performance indicators reported by KMGI in 2015 on occupational safety

\begin{tabular}{|c|c|c|c|}
\hline REFINING BU & 2013 & 2014 & 2015 \\
\hline FA - First Aid Cases & 0 & 1 & 0 \\
\hline FTL-Fatalities & 0 & 0 & 0 \\
\hline FTR-Fatality Incident Rate & $0 \%$ & $0 \%$ & $0 \%$ \\
\hline LTI-Loss Time Injury & 3 & 0 & 4 \\
\hline LTIF-Loss Time Injury Frequency & $1.37 \%$ & $0 \%$ & $1.61 \%$ \\
\hline TRI - Total Recordable Injuries & 3 & 0 & 4 \\
\hline TRIR - Total Recordable Injuries Rate & $1.37 \%$ & $0 \%$ & $1.61 \%$ \\
\hline FR - Frequency Rate & $1.37 \%$ & $0 \%$ & $1.61 \%$ \\
\hline SR-Severity Rate & $1.37 \%$ & $0 \%$ & $1.61 \%$ \\
\hline GROUP & 2013 & 2014 & 2015 \\
\hline FA - First Aid Cases & 3 & 9 & 5 \\
\hline FTL-Fatalities & 0 & 0 & 0 \\
\hline FTR-Fatality Incident Rate & $0 \%$ & $0 \%$ & $0 \%$ \\
\hline LTI - Loss Time Injury & 5 & 4 & 6 \\
\hline LTIF-Loss Time Injury Frequency & $0.34 \%$ & $0.27 \%$ & $0.42 \%$ \\
\hline TRI - Total Recordable Injuries & 5 & 4 & 6 \\
\hline TRIR - Total Recordable Injuries Rate & $0.34 \%$ & $0.27 \%$ & $0.42 \%$ \\
\hline FR - Frequency Rate & $0.34 \%$ & $0.27 \%$ & $0.42 \%$ \\
\hline SR - Severity Rate & $0.34 \%$ & $0.27 \%$ & $0.42 \%$ \\
\hline
\end{tabular}

Source: KMGI, 2015: 54

The analysis of the press release published less than two months before the accident provides further insights. On the one hand, the document has a suggestive title that highlights that "Petromidia Refinery [is] operated according to the legislation in force on occupational safety". The following quote illustrates how the title of the press release is repeated in the first paragraph to highlight this aspect. Moreover, the company states that a ,special attention" is paid to the employees and their working conditions:

„Petromidia refinery is operated according to the applicable law in occupational safety and a healthy climate is being ensured for the employees. The industrial platform is aligned to the national 
and European standards of security and occupational safety. KMG International Group as the owner of Petromidia and Vega refineries complies with all legal obligations concerning security and occupational safety of employees, paying special attention to ensure operational safety and health of employees. In this regard, since 2010, the company invested over 120 million USD in building new units and in the modernization, upgrading and automation of existing units, i.e. those who have a high operational risk (coker and gas desulphurization units). The investments led to increasing the level of operational safety and improving the working conditions for employees." (KMGI CP, 2016)

The sustainability report for 2016 reflects the frequent use of the term "safety". This word is repeated in subtitles such as:

„Safety first” (KMGI, 2016)

(KMGI, 2016)

„Everything begins with the safety and well-being of our employees"

„Safety above all else” (KMGI, 2016)

„Safety training will always be part of our culture" (KMGI, 2016)

„Our focus on safety and employee well-being extends to everyone we work with" (KMGI, 2016)

„Safety policy, of utmost importance” (KMGI, 2016)

„Leading the way in workforce safety” (KMGI, 2016)

Moreover, in 2016 the company's code of conduct was amended. The following quotes reflect a comparison between the statements made in each of the two years. It can be noticed the emphasis placed in 2016 on occupational safety.

„Our people: We place the highest priority on the needs of our employees. Our actions are always determined by their dynamism, contemporary spirit, creativity and experience." (KMGI, 2015)

„Our people: We place the highest priority on the needs of our employees. Our actions are always determined with their safety and well-being in mind." (KMGI, 2016)

The analysis of the message of the CEO highlighted the frequent use of the word "safety". The following examples illustrate this observation:

„...we are committed to positively contributing to our local communities, keeping our employees safe and protecting the planet we all share." (KMGI, 2016) 
„Whether it's employee safety, ethical business practices, or social progress, we will continue to push forward and establish KMG International as a leader in weaving sustainability standards into the fabric of daily operations." (KMGI, 2016)

„Despite our diligent efforts to improve overall safety management, we regret to report that on August 22, 2016, two Rominserv contractors lost their lives due to a vacuum gas oil (VGO) leak. Our hearts go out to their families, and along with that comes a promise that we will work our hardest to ensure something like this never happens again at KMGI. To prevent this from happening in the future, we spent months analyzing the situation and have since implemented multiple new policies and procedures to better protect our employees and contractors." (KMGI, 2016)

„In addition to the actions taken to address this specific incident, we continue to focus on contractor safety, vehicle and machinery safety and fall prevention and protection with a newly improved and much more comprehensive safety training system." (KMGI, 2016)

„As we move into 2017 and beyond we plan to double down on safety and sustainability.” (KMGI, 2016)

Moreover, after reporting the incident, the message takes on a positive tone. Although the CEO admits that the loss of human lives cannot be compensated, the presentation of positive aspects is intended to reduce the negative impact of the incident. According to Lindblom (1994, in Gray et al., 1995), this is a strategy of legitimization through which the reader's attention is redirected.

„Even though this was a terrible tragedy and no success can compensate for loss of life, we are fortunate that aside from this incident, the remainder of the highlights are mostly positive in nature. We are proud to report some significant steps forward in how KMGI treats our greatest asset: our people.” (KMGI, 2016)

The report also includes an interview with the vice president responsible for development and organizational strategies. The following quote contains his answer to a question addressing the issue of safety at work:

„This topic has really hit close to home because of the unfortunate event that occurred this last here where a contractor lost his life. We have vowed to never let an incident like this happen again and learn from the mistakes that led to this tragedy. We believe that safety is a culture, not just an action, and we're 
doing everything we can to create a culture of safety first. We have implemented and continue to reinforce safety behaviors that align with our core value of safety first and hold all employees responsible for ensuring we operate safely and reliably. We want everyone to go home safe, happy, and healthy each night. Companywide we've recorded nearly 40,000 hours of safety and health training in 2016, and will continue to emphasize this important issue to employees, contractors, site visitors, and even the community as a whole." (KMGI, 2016)

The quote includes a repetition of the word 'safety' and its various forms, namely 'safe' and 'safely'. By using these words for seven times in a paragraph, a positive feeling is sent to the reader. Moreover, the list "safe, happy, and healthy" is used in order to better emphasise the message. The intention to extend the concept of security to other categories of stakeholders is also used. This is accomplished through the use of the list "employees, contractors, site visitors, and even the community as a whole".

However, the above quote includes a mistake. In particular, it is mentioned that only one person lost his life as a result of the accident, when in fact two people died. The error is surprising given the important function of the interviewee. Moreover, the same mistake occurs in the table with indicators related to occupational safety. As can be seen in Figure 2, only one person was reported in the "Fatalities" category.

Figure 2. Performance indicators reported by KMGI in 2015 on occupational safety

$\begin{array}{lrr} & & \\ \text { GRO UP QHSE KPI } & 2015 & 2016 \\ \text { FTL - Fatalities } & 0 & 1 \\ \text { FTR - Fatality Incident Rate } & 0 \% & 8.16 \% \\ \text { LTI - Loss Time Incident } & 4 & 12 \\ \text { LTIF - Loss Time Injury Frequency } & 1.61 \% & 0.98 \% \\ \text { TRI - Total Recordable Injuries } & 4 & 12 \\ \text { TRIR - Total Recordable Injuries Rate } & 1.61 \% & 0.98 \% \\ \text { DAWC - Days Away from Work Case } & - & 11 \\ \text { FR - Frequency Rate (DAFWCR) } & 1.61 \% & 0.90 \% \\ \text { RWDC - Restricted Work Days Case } & - & 0 \\ \text { MTC - Medical Treatment Case } & - & 0 \\ \text { FA - First Aid Cases } & 0 & 5 \\ & & \end{array}$

Source: KMGI, 2016: 20 
In addition, if we compare this table with the one presented in the sustainability report for 2015, we can note that the values of the indicators for 2015 do not correspond. What is more, the results for the refining segment are not included in the current sustainability report. One possible explanation could be the group's intention to point out that it does not have a "history" associated with accidents resulting in the death of employees. Coombs (2004) mentions that such a history could amplify the negative image associated with the event, thus influencing the perception of relevant stakeholders and implicitly the organizational reputation.

Consequently, the error is in direct contrast to a statement included in the sustainability report, a statement whose credibility can therefore questioned:

„We know each employee is more than a number." (KMGI, 2016)

The lists are once again used in order to reflect the group' objectives on occupational safety. Moreover, through the use of evaluation, it is highlighted that these represent "our top priority":

„safety and worker health are our top priority and we are determined to zero injuries, incidents and spills at our operational sites." (KMGI, 2016)

„At KMG International, each member of our team is a talented and unique individual, and nothing surpasses our desire to see them healthy, safe and proud of the work they do each day." (KMGI, 2016)

Moreover, a positive evaluation of the employee' training process and of the committees dealing with these issues is made. The adjectives 'functioning' and 'active' are used in this respect, thus emphasizing that their existence is not purely formal.

„we have also implemented and continuously trained our employees on a strict and comprehensive safety policy." (KMGI, 2016)

„Our safety training system is robust, ongoing and consistent." (KMGI, 2016)

„Additionally, functioning and active health and safety committees continue to meet on a regular basis." (KMGI, 2016) 
The following excerpts illustrate examples in which repetition is used as a rhetorical device to highlight the message conveyed. As in the previous examples, the word "safety" is a keyword that is highlighted throughout the report. In particular, in each of the following quotes this term is used for four times.

„100\% safety is our goal. To do this we are striving to a culture of safety where all employees understand the risks they face every day, and are fully trained to mitigate these risks for their safety and the safety of their colleagues and community" (KMGI, 2016)

„To ensure the safety and well-being of each employee we have not only implemented safety standards and procedures across all areas, but more importantly, we continue to build a culture of safety first. We believe each of our team members have a fundamental right to safety in the workplace, and it's our duty to preserve and protect that right." (KMGI, 2016)

In addition, in the following quote we can notice the repetition of the verb "to stop" to highlight the group's intention to prevent the accidents, "always advising" employees to give up behaviours that may endanger them. As such, a causal relationship is indirectly established between the accident rate and employees. In turn, this may reflect inappropriate training on safety issues, a major requirement in the oil and gas industry.

„As the message of safety first continues to flow down from KMGI leadership, and we aim at implementing industry's best safety programs, increasing leadership engagement, always advising workers to stop unsafe behaviors and meticulously analyzing the causes of the incidents in an effort to stop them from ever occurring again in the future." (KMGI, 2016)

Moreover we can note the repetition of the words „safe" and „healthy" and the use of the list "safe, healthy and happy" in order to better emphasise the message.

„Part of being a responsible member of our marketplace is keeping our workers safe and healthy, and this is a responsibility we take very seriously. Every year we work to improve our processes and procedures so that every employee can return to their family each evening safe, healthy and happy." (KMGI, 2016) 
The results support the observation made by Davison (2008):

„It is of interest that the lists generally consist of three elements: enough to underline the message, and subtly suggest more, without becoming monotonously repetitive." (Davison, 2008: 813)

Following a „thorough incident evaluation”, the group mentions in the report that certain preventive measures have been taken. The following quotes illustrate some examples:

„A policy has been implemented regarding piping system comprehension. If an employee or contractor does not fully understand the piping system, a temporary option is no longer acceptable. The immediate area and operation are shut down until a viable replacement is selected." (KMGI, 2016)

„When working in potential fire and scalding risk environments, all employees and contractors are now required to wear fire retardant PPE at all times." (KMGI, 2016)

„Rompetrol will be piloting and testing an e-PTW system that will allow operational personnel to spend more time checking risks are mitigated rather than filling out excessive paperwork." (KMGI, 2016)

As the group operates in the oil and gas industry, we may think about the potential consequences that may arise if an employee or contractor "does not fully understand the piping system”. Consequently, it becomes surprising that a „temporary option” was previously accepted.

The second quote supports the previous statement. Although the acronym "PPE" is not explained in the report, it means personal protective equipment. It follows that prior to the adoption of this measure, employees and contractors worked in conditions where a fire could start, without having a fire retardant equipment. In this context, the usefulness of the equipment used before the accident becomes irrelevant as it had only the status of a uniform, without providing protection.

Finally, the third quote states that the time spent in order to complete documents will be used in the future to identify and minimize risks. In other words, this new measure suggests that this was a potential factor that limited the possibility of identifying the risk. However, this contradicts what prosecutors claimed. Particularly they said that starting with August 19, a number of 1,600,000 alarms were registered as well as the fact that: 
"The decision to stop the transport through the respective pipeline was not taken, considering that it is better to continue with the production even if the pipeline was drilled." (Niță, in Litoral TV, 2016)

The implementation of these new measures contradicts the statement made in the press release published less than two months before the accident. As it was demonstrated in the study, the group claimed that the refinery is operated in accordance with national and European standards for occupational safety, with „special attention” being paid to employees and the conditions in which they operate.

The analysis of the corporate narratives published by KMGI in 2015 and 2016 highlighted the tendency to positively evaluate corporate performance related to occupational safety. As such, both the sustainability report and the press release issued by the company before the blast, illustrate the increased attention that the entity paid to safety measures and its employees.

Following the incident, a change in the use of corporate narratives was noticed. Particularly, the company focused on the use of repetitions, positive evaluations and biased use of performance comparisons. In other words, it was documented the tendency to use reporting in order to defend corporate legitimacy. Another strategy of legitimization involved highlighting the measures taken by the company following the accident. However, the new measures were in direct contrast with the statements made in the past, which underlined the fact that the group carried out its activities according to the regulations in force. Last but not least, the company tried to restore its legitimacy by redirecting readers' attention to the positive aspects. (Lindblom, 1994, in Gray et al., 1995).

In order to better interpret these results, it is necessary to mention the fact that in 2015 KMGI requested the independent opinion of the Association for Community Relations. However, the 2016 sustainability report does not include such an opinion, which may suggest the company's intention to use corporate narratives in order to manipulate the perception of relevant stakeholders.

\section{Conclusions}

The study analysed the use of corporate narratives in disclosing occupational safety issues. The case study focused on the sustainability reports and press releases published by KMGI in 2015 and 2016. During this period, a negative event took place that threatened the organizational image associated with the concept of occupational safety. The results highlighted a trend towards the use of positive evaluations of organizational performance. In addition, after the incident a change in the use of narratives was documented. This entailed the use of several impression 
management strategies in order to defend the legitimacy and to favourably shape the corporate image associated with occupational safety (Cho, 2009; Beelitz \& MerklDavies, 2012).

The study complements previous research on social and environmental disclosures that evaluated the biased use of tone (Cho et al., 2010) and graphs (Cho et al., 2012a, $2012 \mathrm{~b}$ ) as it considers the use of other impression management strategies: repetition, evaluation and the biased use of performance comparisons. What is more, the study contributes to previous research that focused mainly on environmental disclosures (Cho \& Patten, 2007; Cho et al., 2010) by illustrating a case study that reveals occupational safety issues.

This case does not have the same magnitude as other catastrophes which involved the oil industry such as the Exxon Valdez oil spill in 1989 (Patten, 1992) or the BP Deepwater Horizon oil spill in 2010 (Kassinis \& Panayiotou, 2018). However, the idea of "magnitude" may be just a matter of time as long as corporate narratives regarding social and environmental issues are not further transposed in practice by the companies operating in this industry. Moreover, although KMGI issues sustainability reports in accordance with Global Reporting Initiative guidelines, stakeholders may "fail to realize the inherent biases in the reporting, and continue to laud the practice as evidence of increased corporate transparency and accountability" (Cho et al., 2012b: 35).

Consequently, this paper may have potential implications for several users of corporate narratives such as journalists and non-governmental organizations. While these categories of users may play a significant role in shaping public' perception, they need to better filter the information disseminated by companies. In addition, this study may be of interest for researchers, as the analysis reflects textual elements that may be subject of impression management.

\section{Acknowledgements}

A special thank you to Cătălin Albu and Sebastian Hoffmann, for the time and attention they gave this paper to its advantage. I also acknowledge the insightful feedback received at the 2020 CSEAR Emerging Scholar Colloquium and the suggestions provided by the editor in chief of the Journal (Nadia Albu) throughout the revision process. A previous version of this paper has also been presented at the 2019 IAAER ACCA Central and Eastern European Emerging Accounting Scholars Research Workshop in Bucharest. This paper was co-financed by The Bucharest University of Economic Studies during my PhD program. 


\section{References}

Adams, C. A. (2004) „The Ethical, Social and Environmental Reporting Performance-Portrayal Gap", Accounting, Auditing and Accountability Journal, vol. 17, no. 5: 731-757.

Albu, N., Albu, C. N., Dumitru, M., \& Dumitru, V. F. (2013) „Plurality or convergence in sustainability reporting standards?”, Amfiteatru Economic, vol. 15: 729-742.

Arndt, M., \& Bigelow, B. (2000) „Presenting structural innovation in an institutional environment: Hospitals' use of impression management", Administrative Science Quarterly, vol. 45, 494-522.

Băleanu, T. E., Chelcea, L., \& Stancu, A. (2011) „The social responsibility of the top 100 Romanian companies. An analysis of corporate websites", Amfiteatru Economic, vol.13, 235-248.

Beelitz, A., \& Merkl-Davies, D. M. (2012) „Using discourse to restore organisational legitimacy: 'CEO-speak'after an incident in a German nuclear power plant", Journal of Business Ethics, vol.108, 101-120.

Boiral, O. (2013) „Sustainability Reports as Simulacra? A Counter-Account of A and A+ GRI Reports", Accounting, Auditing and Accountability Journal, vol. 26, no. 7: 1036-1071.

Brennan, N.M., Guillamon-Saorin, E. \& Pierce, A. (2009) „Impression management: Developing and illustrating a scheme of analysis for narrative disclosures - A methodological note", Accounting, Auditing \& Accountability Journal, vol. 22, no. 5: 789-832.

Breton, G., \& Côté, L. (2006) „Profit and the legitimacy of the Canadian banking industry", Accounting, Auditing \& Accountability Journal, vol.19, 512-539.

Campbell, D., Craven, B. \& Shrives, P. (2003) „Voluntary social reporting in three FTSE sectors: a comment on perception and legitimacy", Accounting, Auditing \& Accountability Journal, vol. 16, no. 4: 558-581.

Cho, C. H. (2009) „Legitimation strategies used in response to environmental disaster: A French case study of Total S.A.'s Erika and AZF incidents", European Accounting Review, vol. 18, no. 1: 33-62.

Cho, C.H., Michelon, G. and Patten, D.M. (2012a) „Enhancement and obfuscation through the use of graphs in sustainability reports: An international comparison", Sustainability Accounting, Management and Policy Journal, vol. 3, no. 1: 74-88.

Cho, C.H., Michelon, G. \& Patten, D.M. (2012b) „Impression management in sustainability reports: An empirical investigation of the use of graphs", Accounting and the Public Interest, vol. 12: 16-37.

Cho, C.H. \& Patten, D.M. (2007) „The role of environmental disclosures as tools of legitimacy: A research note", Accounting, organizations and society, vol. 32: 639-647. 
Cho, C.H., Roberts, R.W. \& Patten, D.M. (2010) „The language of US corporate environmental disclosure", Accounting, Organizations and Society, vol. 35: 431-443.

Clatworthy, M.A. \& Jones, M.J. (2003) „Financial reporting of good news and bad news: Evidence from accounting narratives", Accounting and Business Research, vol. 33, no. 3: 171-185.

Clatworthy, M.A. \& Jones, M.J. (2006) „Differential patterns of textual characteristics and company performance in the chairman's statement", Accounting, Auditing \& Accountability Journal, vol. 19, no. 4: 493-511.

Coombs, W. T. (2004) „Impact of past crises on current crisis communication: Insights from situational crisis communication theory", Journal of Business Communication, vol.41, 265-289.

Craig, R., \& Amernic, J. (2004) „The deployment of accounting-related rhetoric in the prelude to a privatization", Accounting, Auditing \& Accountability Journal, vol.17, 41-58.

Craig, R., \& Amernic, J. (2006) „The mobilization of accounting in preening for privatization", Accounting, Auditing \& Accountability Journal, vol.19, 82-95.

Craig, R., \& Amernic, J. (2008) „A privatization success story: Accounting and narrative expression over time", Accounting, Auditing \& Accountability Journal, vol.21, 1085-1115.

Dando, N., \& Swift, T. (2003) „Transparency and assurance minding the credibility gap", Journal of Business Ethics, vol.44, 195-200.

Davison, J. (2008) „Rhetoric, repetition, reporting and the 'dot.com' era: words, pictures, intangibles", Accounting, Auditing and Accountability Journal, vol. 21, no. 6: 791-826.

Deegan, C. (2002) „Introduction: The legitimizing effect of social and environmental disclosures: A theoretical foundation", Accounting, Auditing and Accountability Journal, vol. 15, no. 3: 282-311.

Deegan, C., Rankin, M. \& Tobin, J. (2002) „An examination of the corporate social and environmental disclosures of BHP from 1983-1997: A test of legitimacy theory", Accounting, Auditing \& Accountability Journal, vol. 15, no. 3: 312-343.

Dumitru, M., Dyduch, J., Gușe, R. G., \& Krasodomska, J. (2017) „Corporate reporting practices in Poland and Romania-an ex-ante study to the new nonfinancial reporting European directive", Accounting in Europe, vol.14, 279-304.

Fairclough, N. (2003) Analysing discourse: Textual analysis for social research, London: Routledge.

Garcia Osma, B. \& Guillamón-Saorín, E. (2011) „Corporate governance and impression management in annual results press releases", Accounting, Organizations and Society, vol. 36, no. 4: 187-208.

Goffman (1956), The Presentation of self in everyday life, Edinburgh: University of Edinburgh Social Sciences Research Centre. 
Gray, R. (2006) „Social, environmental and sustainability reporting and organisational value creation? Whose value? Whose creation?", Accounting, Auditing \& Accountability Journal, vol.19, 793-819.

Gray, R., Kouhy, R., \& Lavers, S. (1995) „Corporate social and environmental reporting: a review of the literature and a longitudinal study of UK disclosure", Accounting, Auditing \& Accountability Journal, vol.8, 47-77.

Guillamón-Saorín, E. \& Martínez-López, F.J. (2013) „Corporate financial communication and the internet: Manipulating investor audiences?", Online Information Review, vol. 37, no. 4: 518-537.

Gușe, R. G., Almășan, A., Circa, C., \& Dumitru, M. (2016) „The role of the stakeholders in the institutionalization of the CSR reporting in Romania", Accounting and Management Information Systems, vol.15, 304.

Hooghiemstra, R. (2000) „Corporate communication and impression managementnew perspectives why companies engage in corporate social reporting", Journal of Business Ethics, vol.27, 55-68.

Hughes, S. B., Anderson, A. \& Golden, S. (2001) „Corporate environmental disclosures: Are they useful in determining environmental performance?", Journal of Accounting and Public Policy, vol. 20, no. 3: 217-240.

Kassinis, G. \& Panayiotou, A. (2018) „Visuality as greenwashing: The case of BP and Deepwater Horizon", Organization \& Environment, vol. 31, no. 1: 25-47.

KMGI (2015) „Sustainability report 2015”, https://kmginternational.com/sustainability.

KMGI (2016) „Sustainability report 2016”, https://kmginternational.com/sustainability.

KMGI (2017) „Sustainability report 2017”, https://kmginternational.com/sustainability.

KMGI CP (2016) „Petromidia refinery is operated according to the applicable law in occupational safety", https://kmginternational.com/mediaroom/pressreleases/petromidia-refinery-is-operated-according-to-the-applicable-law-inoccupational-safety-id-1006-cmsid-471.

Krippendorff, K., (2004), Content analysis. An introduction to its methodology, 2nd edn., Thousand Oaks: Sage.

Laine, M. (2009) „Ensuring legitimacy through rhetorical changes? A longitudinal interpretation of the environmental disclosures of a leading Finnish chemical company", Accounting, Auditing \& Accountability Journal, vol. 22, no. 7: $1029-1054$.

Lightstone, K., \& Driscoll, C. (2008) „Disclosing elements of disclosure: a test of legitimacy theory and company ethics", Canadian Journal of Administrative Sciences, vol. 25, 7-21.

Litoral TV (2016) „Dosarul tragediei de la Petromidia Năvodari a ajuns în instanță", https://www.youtube.com/watch?v=Vp-aZRWDils".

Mahadeo, J.D., Oogarah-Hanuman, V. \& Soobaroyen, T. (2011) „Changes in social and environmental reporting practices in an emerging economy (2004-2007): 
Exploring the relevance of stakeholder and legitimacy theories", Accounting Forum, vol. 35, no. 3: 158-175.

Mäkelä, H. \& Laine, M. (2011) „A CEO with many messages: Comparing the ideological representations provided by different corporate reports", Accounting Forum, vol. 35, no. 4: 217-231.

Matilal, S. \& Höpfl, H. (2009) „Accounting for the Bhopal disaster: footnotes and photographs", Accounting, Auditing \& Accountability Journal, vol. 22, no. 6: 953-972.

Mediafax (2016) „Rompetrol Rafinărie, trimisă în judecată în urma incendiului în care au murit două persoane" [Rompetrol Rafinărie, sued after the incident in which two people died], Mediafax, 14 December, available on-line at https://www.mediafax.ro/social/rompetrol-rafinarie-trimisa-in-judecata-inurma-incendiului-in-care-au-murit-doua-persoane-16027771 (Accessed 9 November 2018).

Merkl-Davies, D.M. \& Brennan, N.M. (2007) „Discretionary disclosure strategies in corporate narratives: Incremental information or impression management?", Journal of Accounting Literature, vol. 26, no. 1: 116-194.

Merkl-Davies, D.M., Brennan, N.M. \& McLeay, S.J. (2011) „Impression management and retrospective sense-making in corporate narratives: A social psychology perspective", Accounting, Auditing \& Accountability Journal, vol. 24, no. 3: 315-344.

Merkl-Davies, D.M. \& Koller, V., (2012) „'Metaphoring'people out of this world: A Critical Discourse Analysis of a chairman's statement of a UK defence firm", Accounting Forum, vol. 36, no. 3: 178-193.

Moneva, J. M., Archel, P., \& Correa, C. (2006) „GRI and the camouflaging of corporate unsustainability”, Accounting Forum, vol. 30, 121-137).

O’Donovan, G., (2002) „Environmental disclosures in the annual report: Extending the applicability and predictive power of legitimacy theory", Accounting, Auditing \& Accountability Journal, vol. 15, no. 3: 344-371.

Obrad, C., Petcu, D., Gherheş, V., \& Suciu, S. (2011) „Corporate social responsibility in Romanian companies-between perceptions and reality", Amfiteatru Economic, vol. 13, 43-55.

OMFP 1938 (2016). Ordin nr. 1938/2016 privind modificarea şi completarea unor reglementări contabile, publicat în M.Of. nr. 680.

Patten, D. M. (1992) „Intra-industry environmental disclosures in response to the Alaskan Oil Spill: A note on legitimacy theory", Accounting, Organizations and Society, vol.17, no. 5: 471-475.

Patten, D. M. (2002) „The relation between environmental performance and environmental disclosure: A research note", Accounting, Organizations and Society, vol. 27, no. 8: 763-773.

Pollock, T., \& Rindova, V. (2003) „Media legitimation effects in the market for initial public offerings", Academy of Management Journal, vol.46, 631-42. 
Price, S.M., Doran, J.S., Peterson, D.R. \& Bliss, B.A. (2012) „Earnings conference calls and stock returns: The incremental informativeness of textual tone", Journal of Banking \& Finance, vol. 36: 992-1011.

Rodrigue, M. (2014) „Contrasting Realities: Corporate Environmental Disclosure and Stakeholder-Released Information", Accounting, Auditing and Accountability Journal, vol. 27, no. 1: 119-149.

Rodrigue, M., Cho, C. H. \& Laine, M. (2015) „Volume and Tone of Environmental Disclosure: A Comparative Analysis of a Corporation and its Stakeholders", Social and Environmental Accountability Journal, vol. 35, no. 1: 1-16.

Schrand, C.M. \& Walther, B.R. (2000) „Strategic benchmarks in earnings announcements: The selective disclosure of prior-period earnings component", The Accounting Review, vol. 75, no. 2: 151-177.

Short, J.C. \& Palmer, T.B. (2003) „Organizational performance referents: An empirical examination of their content and influences", Organizational Behavior and Human Decision Processes, vol. 90: 209-224.

Suchman, M. C. (1995) „Managing legitimacy: Strategic and institutional approaches", Academy of Management Review, vol.20, 571-610.

Tilling, M. V., \& Tilt, C. A., (2010) „The edge of legitimacy: Voluntary social and environmental reporting in Rothmans' 1956-1999 annual reports", Accounting, Auditing \& Accountability Journal, vol.23, 55-81.

Tregidga, H. \& Milne, M.J. (2006) „From sustainable management to sustainable development: a longitudinal analysis of a leading New Zealand environmental reporter", Business Strategy and the Environment, vol. 15: 219-241.

Zaharia, R. M., \& Grundey, D. (2011) „Corporate social responsibility in the context of financial crisis: A comparison between Romania and Lithuania", Amfiteatru Economic, vol.13, 195-206. 